Sustainable Development and Planning X 941

\title{
URBAN AGRICULTURE AND SACRED LANDSCAPE: ANURADHAPURA SACRED CITY, SRI LANKA
}

\author{
WASANA DE SILVA \\ Department of Architecture, University of Moratuwa, Sri Lanka
}

\begin{abstract}
One of the first cities, Anuradhapura (377 BCE-1017CE) remains a world heritage site in Sri Lanka. Apart from the great Buddhist architectural edifices, agriculture landscape significant in this city is apparent in creating a Buddhist sacred landscape: large water tanks, paddy fields, and canal systems are an essential part of the city landscape and the social/cultural system. This research examines how and why these large water tanks and paddy fields are incorporated in the ancient city concept to achieve a Buddhist sacred place, thus a sustainable city and society. The research examines the ancient city concepts and evaluates Anuradhapura city through different time periods, focusing on the agricultural landscape, Buddhist sacred city, and everyday life performances around these. The research methodology synthesises aspects of phenomenology, anthropo-ethnography, landscape analysis, Buddhist philosophy, and historical analysis. In Anuradhapura sacred city, the everyday life of people has been bounded around large water tanks and vast paddy fields for the maintenance of the city as well as to achieve sacred experiences by engaging with sacred natural landscape elements through everyday performing and dwelling in the city. Thus, urban agriculture acts as a mechanism of engaging the everyday life of the people with the landscape and uplift the nature of the humans and human wellbeing, hence establishes a healthy city, while enhancing the city form and the Buddhist sacred landscape.
\end{abstract}

Keywords: Buddhist sacred landscape, agriculture landscape, everyday performing, human wellbeing.

\section{INTRODUCTION}

Anuradhapura (377BCE-1017 CE) was the first Buddhist city in Sri Lanka, and the great architectural edifices in this city are invaluable sources to understand Buddhist sacred architecture and landscape. The city was nominated under the world heritage list in 1982. Apart from the Buddhist architectural edifices, agriculture landscape significant in this city is apparent in creating Buddhist sacred landscape: large water tanks, paddy fields, and canal systems are an essential part of the city landscape and the social/ cultural system. Images of stupas falling on water bodies; the vicinity of pinnacles of stupas across the paddy lands, and the backdrop of the green undulating landscape increase the Buddhist sacred atmosphere in Anuradhapura. How do people experience these city concepts/ images through everyday life performance, while working in the fields? How do the large water tanks encircling the city and paddy fields coexist with the centre of the city of the sacred urban context? How do these agriculture landscapes incorporate in the city landscape, topography and geography highlighting the Buddhist philosophy, hence, Buddhist sacred city? The monasteries spread over a vast land area, and the number of great stupas suggests the number of population and the related urban context. The large water tanks and paddy fields as food sources may have given a realistic solution for the urban need. Large refectory halls give the evidence of the scale of the donation of food for the brotherhood/ monkhood as a meritorious act of the everyday life of the people. Does it raise the question of what relationships exist between the brotherhood and the everyday life activities of people? How had this interdependence guided the city concept, dwelling patterns, and sustainable city? Can we learn some lessons for today's issues, relating to the authenticity of the food system and feeding cities? Hence, this 
research examines how and why these large water tanks and paddy fields are incorporated in the ancient city concept to achieve a Buddhist sacred place, thus sustainable city, and a society. Therefore, it examines how the agriculture and urbanity co-exist by utilizing topography and geography hence how a Buddhist sacred city has been shaped and evolved throughout history in Anuradhapura. Although, Anuradhapura sacred city has been studied from different perspectives, for example, archaeological studies, architectural studies, Buddhist studies, social/ cultural system, historical studies, irrigation, and engineering aspects, this kind of study has not been carried out so far. The research methodology synthesises aspects of phenomenology, anthropo-ethnography, landscape analysis, Buddhist philosophy, and historical analysis to examine the context. The words, place, sense of place, place attachment, dwelling, process of dwelling and performance are common terms utilized in the discussion. People experience their existence on the earth as dwelling [1], when experiencing the sense of place in the location, where they live. The sense of place signifies an effort to understand the place in relation to the process of dwelling, which is an essential aspect of human nature [2]. Performance indicates the process, through a hard life on the earth, through which the way people work on the earth [3].

\section{THE SITE AND HISTORY}

The location of Sri Lanka is at the south edge of the Indian peninsula, in the Indian ocean. The central mountains of Sri Lanka rise to an elevation of 2,500 $\mathrm{m}$ above the sea level and are surrounded by lowland plains at an elevation of $-75 \mathrm{~m}$ above the sea level. There are many rivers and streams originated from the mountains, flow in an arterial pattern across the lowland plains to the sea. Anuradhapura is located by the side of the Malwathu Oya, in the north-central part of Sri Lanka (Fig. 1), in an elevation of $81 \mathrm{~m}$ above sea level; annual average rainfall is $1450 \mathrm{~mm}$. Temperature varies from $35^{\circ} \mathrm{C}$ to $21^{\circ} \mathrm{C}$ throughout the year.
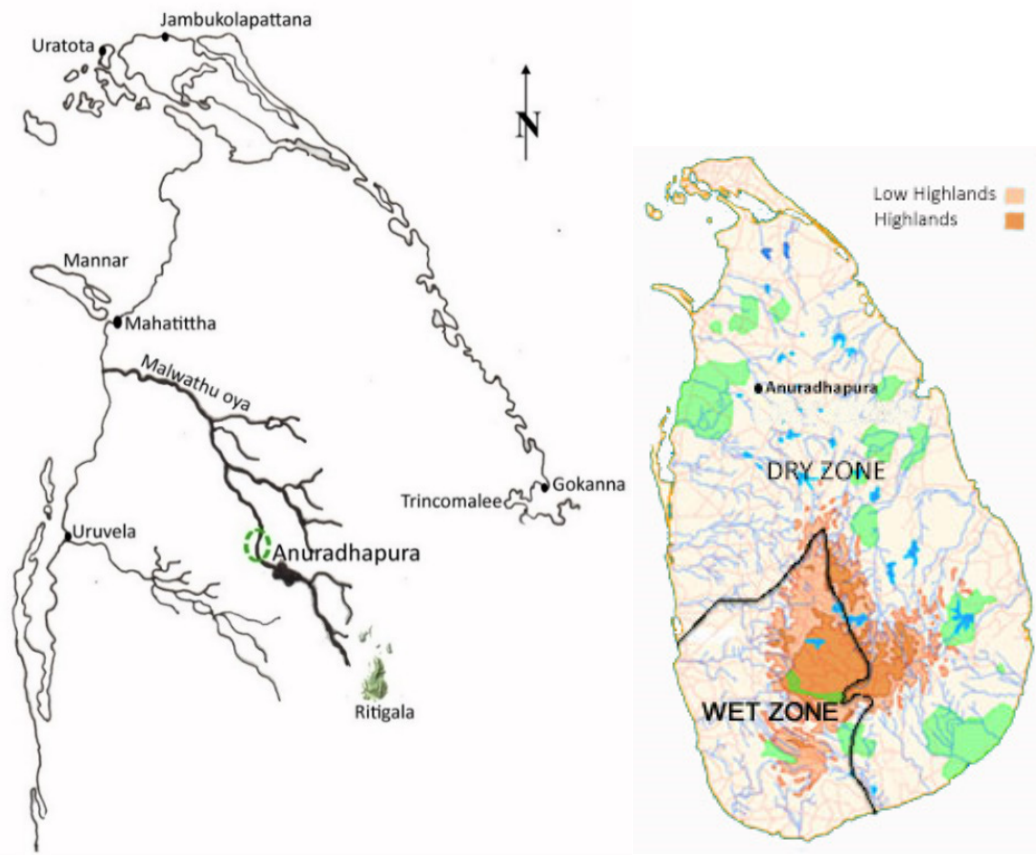

Figure 1: Location of Anuradhapura and ancient seaports. 


\subsection{Geography and topography}

Malwathu Oya originates from the Ritigala mountain, a residual mountain in the dry zone, flows across the plains, towards the north-west, and straight north at Anuradhapura then turns north-west flows to the sea below the Mannar. In the geographical area where Anuradhapura locates, a granite formation, comprised of rocks and boulders, caves and stone terrains is significant, running from the south towards north parallel to the Malwathu Oya, from the west side of the Malwathu Oya. It is now confirmed that the earliest settlements originated along these rocks and cave formations [4]. Also, these rock formations became a medium to express ideas, thoughts, worldviews of a particular culture, still evident in these representing different layers of periods. Some cave arts belong to stone age have been identified in some rock caves, utilized for meditation of Buddhist monks in later periods. Abundant water supply from the river and the linear shape of rocks and caves for life expression, other than the simple need of the shelter, have defined stretch of land area in-between, for the cultivation and farming for the earliest wandering people, to be settled along these areas, to experience the process of dwelling (Fig. 2). In the sacred landscape, rocks and caves, water, mountains, and trees and grooves are identified as essential natural elements [5]. Norberg-Schulz explains the understanding of these natural landscapes as a process, which guides dwelling and existence on the earth, mainly focusing on European context. Therefore, these early settlers of the stone age and later iron age may have experienced sacred dimensions among these natural formations of rocks, boulders, caves, mountains, water, and grooves through inhabitation in the landscape.

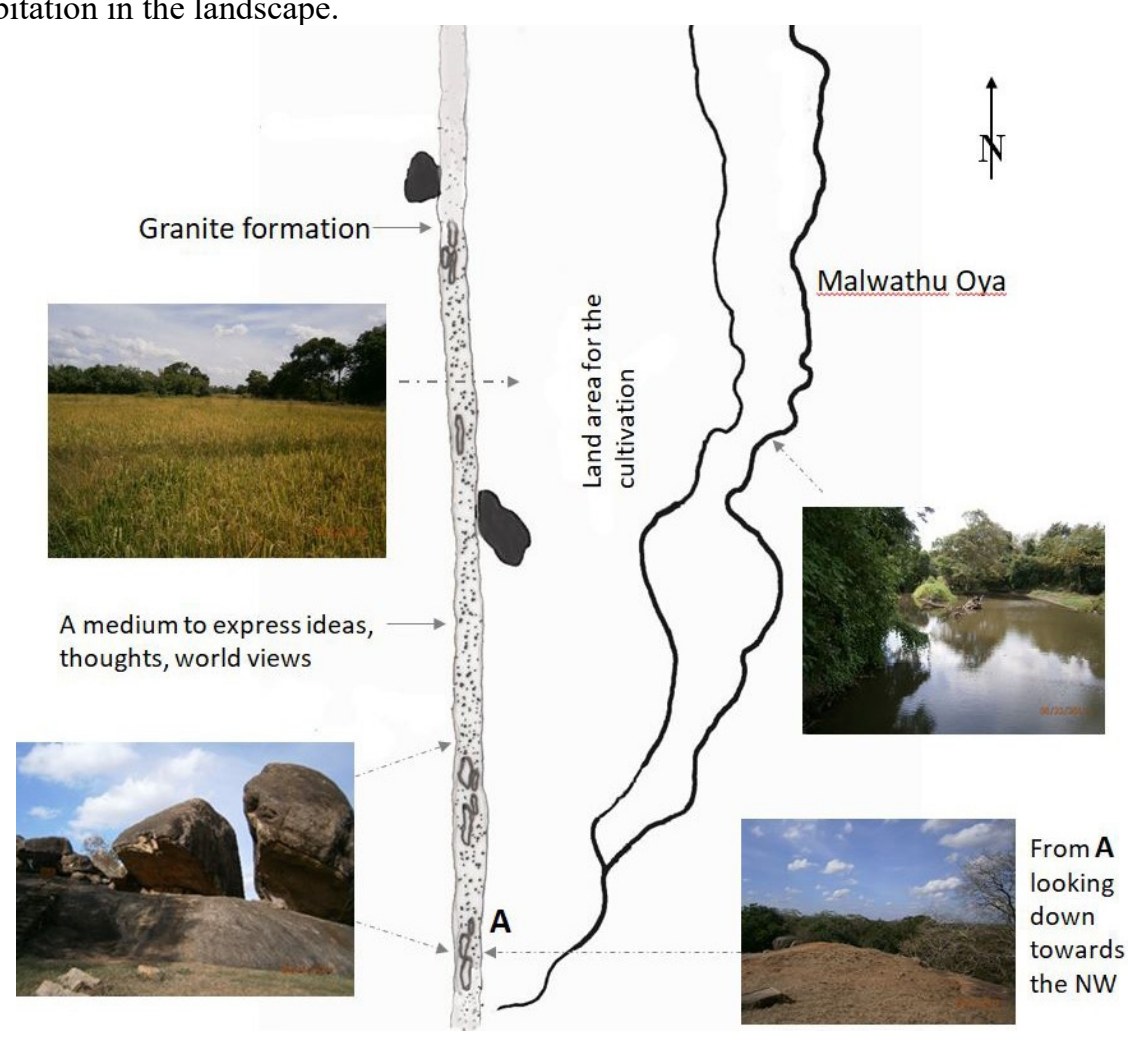

Figure 2: Land in-between river and granite formation, rocks and caves. 


\subsection{History of the civilization (from pre-Vijaya to Vijaya)}

\subsubsection{Pre-Vijaya}

Archaeological excavations provide evidence about human habitations in Anuradhapura up to 3900BCE. Geological studies explain that during middle stone age Sri Lanka had linked to South India, through a stretch of land from Mannar. The last separation from India happened 7000 years before [6]. The beginning of rice cultivation in Asian tropical countries would be 10,000 years ago [7]. It is assumed that pre-historic people from India walked through the sea, by the stretch of land and entered to Sri Lanka, close by the mouth of Malwathu Oya, where flows to the sea. They may have walked along the river to the site where Anuradhapura is today. Ramayana written by Walmiki (500BCE) described Ravana (3000BCE), a king having super-natural powers, settlements having advanced technology and engineering knowledge in Sri Lanka. Excavations from the citadel of Anuradhapura, 10 metres below the present ground surface, have produced substantial evidence of iron technology, breeding of horses and cattle, and paddy cultivation and wheel made clay pottery of high quality, stone tombs, and wattle and daub structures. These were identified using carbon 14 dates, and confirmed, belonged to the periods ranging from $100 \mathrm{AD}$ up to 3900BCE [8]. There was evidence of rice cultivation and artificial irrigation systems before 800BCE in the northern low lands. Therefore, the importance of this natural location/ site for a human settlement has been identified long ago in the human history. According to the written history [9], Buddha visited Sri Lanka, in the ninth month of the enlightenment during 6th century BCE indicate a civilized settlement, intelligent enough to preach the dhamma and receive the Buddhist philosophy. Buddha visited the Anuradhapura during the 3rd visit to Sri Lanka; seated with his disciples, in a meditation posture, at the place where sacred Bodhi tree came afterwards, and did the same, at the place where the great Tupa (present Ruwanwelisaya) and Tuparama came afterwards. These would have marked the important points which could reflect sacred dimensions, in the stretch of land area in-between the rock formation and the Malwathu Oya (Fig. 3) and representing the orientation of the future urban landscape. Norberg-Schulz explains the orientation of a place/ urban place is mainly because of the elements of the natural landscape, geographical formation and geometry, and due to this orientation the "spirit of the place", the genius loci which is intrinsic to that location reflect upon the landscape. Architecture and urban landscape reflect the genius loci (in good architecture).

\subsubsection{Vijaya}

Vijaya (a prince) and his 700 followers from India shipped to the Indian ocean landed on the north-west coast in Sri Lanka, during the 5th to 6th century BCE. Although it is said that Vijaya and later migrations from India introduced new civilizations to Sri Lanka, there are cities, developed civilization, technology, social/cultural systems described in ancient chronicles as well as in archaeological evidence. Therefore, such called "new civilizations" would have been an integrated version with local knowledge, skills, technology, and worldviews. Vijaya founded the city Thambapanni, while his ministers found villages. Anuradhagrama (present Anuradhapura) was built by a man of that name of his ministers near the Kadamba river (present Malwathu Oya). At the request of Vijaya, the king in the city of Madhura, in south India shipped his daughter and seven hundred maidens to Sri Lanka. Mahavamsa describes as, "craftsmen and thousand families of the eighteen guilds were send along with them". The second larger migration happened during the consecration of Panduvasudeva (444-414 BCE), with princes, Bhaddakachana, the daughter of a Sakya king, who arrived Sri Lanka with thirty-two maidens. Her six brothers arrived later to Sri Lanka 


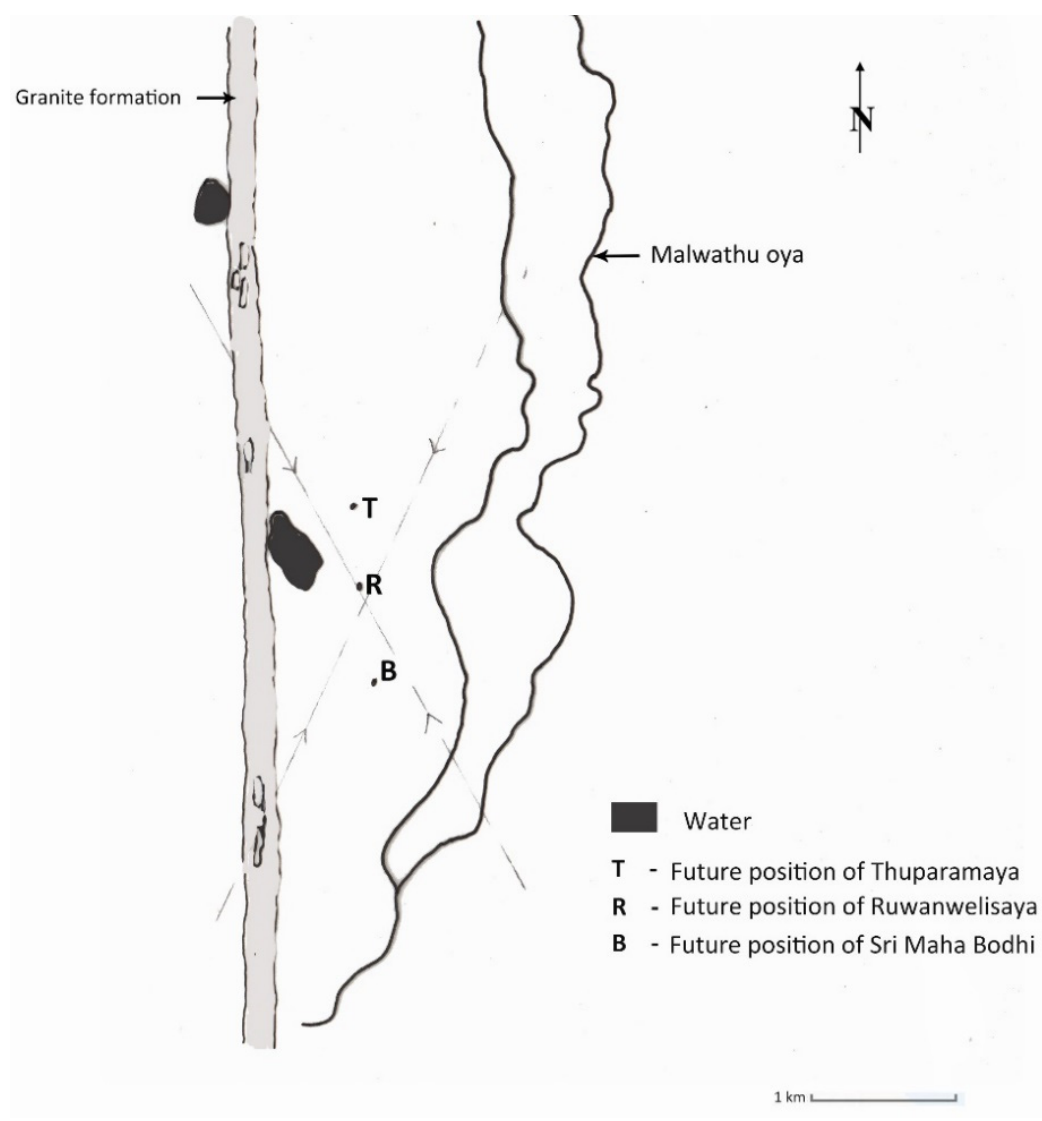

Figure 3: Orientation of the place.

and settled down at different places, as their wish. One of her brother Anuradha built at Anuradhagama (present Anuradhapura). "Anuradha built a tank, and when he had built a palace to the south of this, he took up his abode there". This gives important insight about the settlement and the irrigation. For the building of a tank, he may have utilized indigenous knowledge and the workforce; the storage of water should be for the irrigation and cultivation, as Malwathu Oya nearby well enough for the daily consumption.

\section{RITUALS, MYTHS AND SACRED LANDSCAPE}

Rituals and myths of this context provide rich sources to understand the establishment of these settlements, prevailing worldviews of dwelling (Heidegger), sense of place and place attachment related to the urbanity, agriculture and topography and natural landscape (anthropo-ethnographical perspective), achieving sacred experience.

\subsection{Ploughing ceremony}

Mahavamsa mentioned about a "ploughing ceremony", as an establishment of boundaries, is an important ritual to understand the founding of these settlements and their relationship to the agriculture. It describes, "Pandukabhaya, $(377$ - 307 BCE) the ruler of Lanka established 
the village boundaries over the whole of the island of Lanka". The king Devanampiyatissa (247-207 BCE) asked from the Arhat Mahinda; "Does the doctrine of the Conqueror stand, sir?" However, the thera replied it is not yet until the boundaries are established. "Therefore, establish the boundaries with all speed, taking in the city". Further, this ritual process is explained as a ceremony king adorned with all his ornaments, with the participation of ministers and queens. "The king ploughed a furrow in a circle, making it to begin near the ford on the Kadamba river, and ended it when he (again) reached the river". It might be included of whole city limits, including the inner city and monasteries. Further, he had assigned boundary marks on the furrow that the king had ploughed and had assigned to several other inner buildings/places. According to these descriptions, the king has ploughed the peripheries of the marked places; mark a sanctity for the survival of a settlement upon the agriculture. Also, it symbolizes the anthropological, ethnographical understanding of the placing of settlements; through seedling and agriculture. Ploughing of a land as a means to sanctify and take possession for the purpose of construction or founding of a town [10]. These kinds of ploughing ceremonies are common in Asian regions, still, celebrate in various scales. The earliest written example of ploughing ceremonies is from Mahavamsa [11]. Marking of a circle and circumbulation in these rituals establish important dimensions of the place: centre, enclosure, ordered world and inside and outside. The centre is recognized as sacred, having spiritual experiences in many cultures [12]-[14]. Hence, these rituals symbolize a "performative process" for dwelling, through a hard life, ploughing on the earth, to understand their existence, by understanding the sacred dimensions of the place.

\subsection{Water and cultivation}

Water as a sacred element as well as the practical issue of collecting water for irrigation has shaped the city form, in Anuradhapura. As discussed elsewhere, water is a central element in the sacred landscape, because of many qualities of water. Reflection quality of water symbolizes opposite experience - physical to nonphysical - which is a sacred experience to achieve the sanctity. "The reason for water's religious significance are many; water precedes creation and reabsorbs it and thus is associated with both evolution and dissolution" [15]. There are many instances of spiritual recognition of water described in Mahavamsa; water is associated in consecration festivals, festivals for the victory, confirming agreements and bathing tanks in monasteries as giving a symbolic meaning of new beginning. "Bathing in water is believed to bring about regeneration since immersion implies a temporary regression into the undifferentiated mode of existence while immersion is symbolic of the creation of form" [5]. Water festivals and bathing festivals and many rituals connected with water and bathing in temple ceremonies were common in these traditional settlements, and some are continuing today.

Anuradhagama of Anuradha was a tank fed village (Fig. 4) converted to Anuradhapura (city) by his niece's (Chitta) son Pandukabhaya (377-307 BCE). The tank is done by blocking a water stream by a dam, the collected water becomes a storage tank, conveying through a canal system to paddy fields on the other side of the dam. This simplest version of building a tank establishes an integrated system of village/city, water, cultivation, and sacred landscape, as an independent sustainable unit of balance between the production and the need. There is a small settlement by the side of the paddy fields; agriculture is an integral part of their life rather than an occupation. There are chena cultivation (rainfed) and reserved areas for trees, as for water catchment areas, highlight the ecological balance. These kinds of smaller tanks are organized into cascading sequence; drainage from the paddy fields in the upper part of the cascade flowed into a downstream tank for reuse in the paddy fields below 


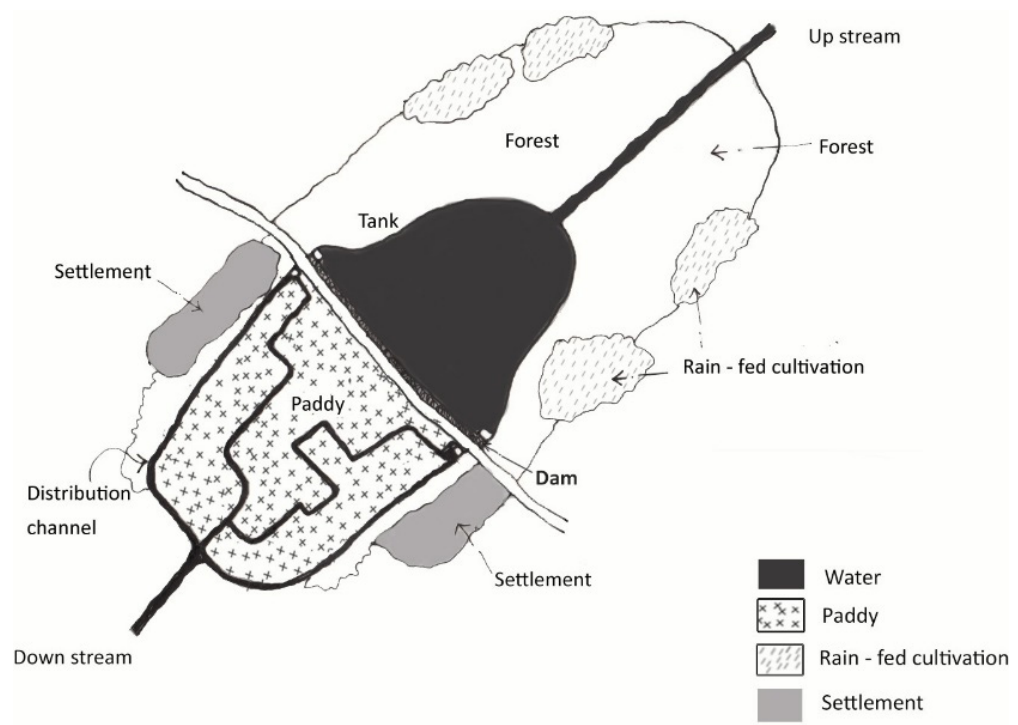

Figure 4: Tank fed village.

[16] had marked network of cascades across the north-central low land of the country. There are many rituals associated with paddy cultivation as evidence of sacred experience they gained through hard life: through the process of dwelling.

\section{ANURADHAPURA BEFORE ARRIVAL OF ARHAT MAHINDA}

\subsection{Anuradhapura of Pandukabhaya (377-307 BCE)}

Pandukabhaya has converted the village Anuradhagama to the city Anuradhapura. According to the instructions given by soothsayers, who has the knowledge about fitting and unfitting sites, he has selected the site, (near the earlier village) for the founding of Anuradhapura. The natural pond used for his consecration and to celebrate the victory was deepened and abundantly filled with water (Mahavamsa). Thus, this city has two or more tanks, for the cultivation. The city has four gates, similar to Aryan cities, however, associated with local concepts, and according to the orientation given by the natural landscape elements as discussed in the above sections. The city is on the left bank of the river, in contrast to Aryan cities on the right bank of the river could be justified in this view. The same area understood as unique in Fig. 3, has been assigned for a "monastery for wandering mendicant monks, and other levels of spiritual observations" (Mahavamsa). There was an area for ascetic life; "a hermitage was made for many ascetics of various heretical sects", and chapels for various deities. Although it describes 850 Candala (for the cleaning purposes of the city), huntsmen, Yonas (merchants), ascetics and wandering mendicant monks, there is no indication of farmers. However, by mentioning, the establishment of the city by ploughing ceremony and by building tanks, cultivation is well recognized, as an integral part of the urban life, monastic life and everyday life of the people. Therefore, Pandukabhaya's city was a performing system in urban scale, integrated with irrigation and cultivation, experiencing sacred dimensions of the landscape, and shaping the city form (Fig. 5). 


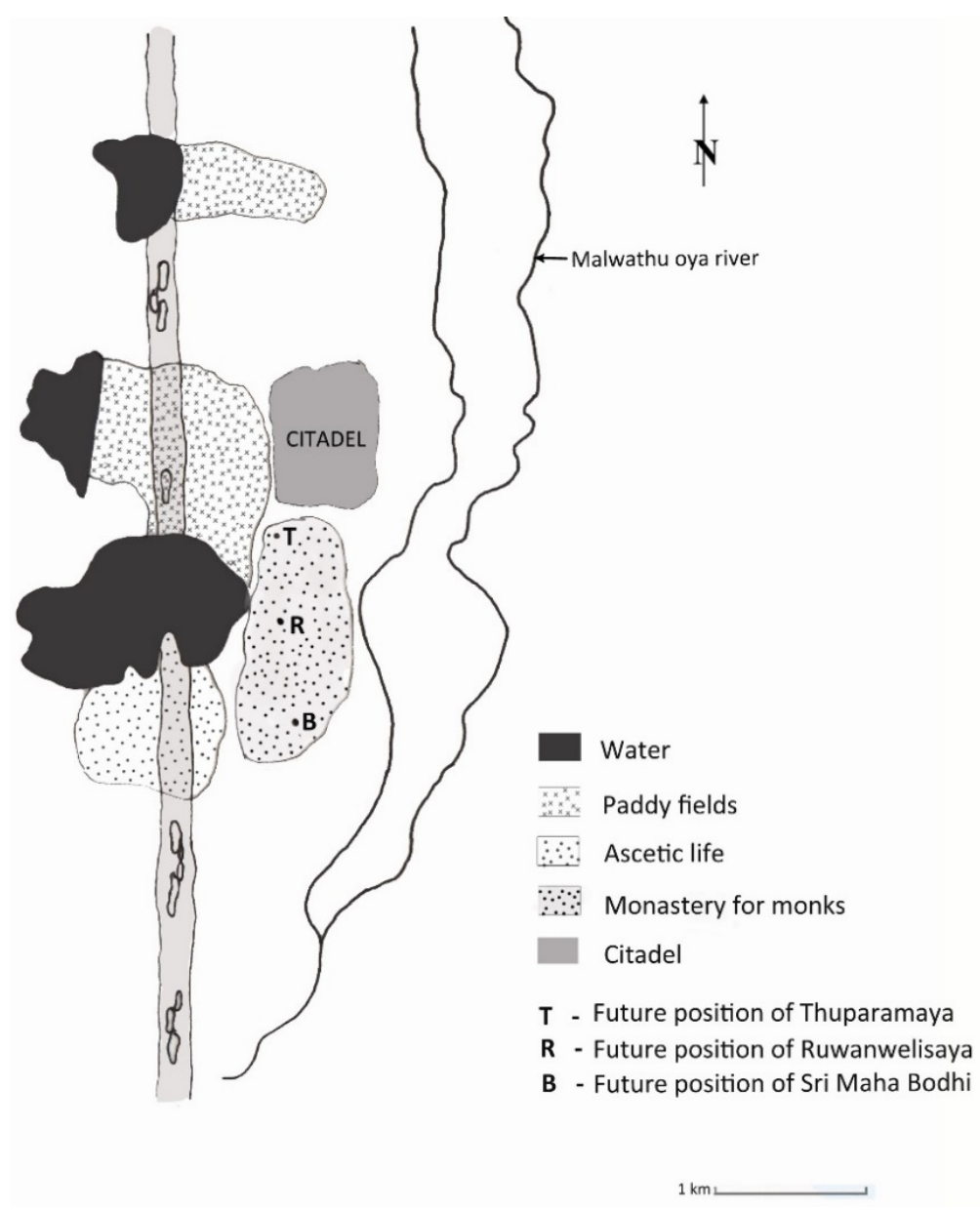

Figure 5: Pandukabhaya's city.

\subsection{Anuradhapura of Devanampiyatissa (247-207 BCE)}

During the reign of Devanampiyatissa, there were two parks in the city; Mahameghavanagarden and Nandana park. According to the description given in Mahavamsa, Mahameghavana was in the same area given for the monastery for "wandering mendicant monks", by Pandukabhaya. It could be assumed the same meditation, asceticism, and monkhood continues to be practised in this area, in between Malwathu Oya, in the vicinity of irrigation landscape, rocks and boulders, caves and stone terrain, under the grooves of trees and not far from the city. The same system of the city concept, established by Pandukabhaya, continued to the period of Devanampiyatissa; by performing various dwelling patterns, including irrigation and cultivation, people continue to experience the peace of the dwelling and the place. It is noted there weren't excess building materials for the prompt construction of a building, for the Arhat Mahinda and the group, who unexpectedly visited, during the reign of Devanampiyatissa. It was used "clay bricks dried speedily with fire, and bricks become black" (Mahavamsa), for the construction of a pasada. It highlights the prevailing 
situation, the peaceful balance between the production and the need, the city as a selfsustained independent unit in an urban scale. Therefore, same as the excess building materials, there had not excess food, for the growing demand arisen due to the increasing number of urban population in monasteries and attracting of worshipers, related services, and the workforce utilized in new constructions, after the arrival of Arhat Mahinda. The next section will discuss how this new demand reshapes the landscape and urban agriculture achieving the new balance and create Buddhist sacred city.

\section{ANURADHAPURA AFTER ARRIVAL OF ARHAT MAHINDA}

Arhat Mahinda, the son of Emperor Asoka India, landed on Mihintale mountain, Anuradhapura (247 BCE), with other six disciples, during the reign of Devanampiyatissa, and had made a significant contribution to advance the urban landscape to the Buddhist sacred city. He himself made the onsite supervision, guiding new developments, selecting sites for fitting and unfitting for building and advised the King, spending the rest of his entire life in Sri Lanka. He was a wise person, attained the highest level of the ordination of arhatship; who receives the multi-dimensional vision of past, present, and future, the highest level of spiritual power.

\subsection{Buddhist philosophy: the four noble truth and cultivation and everyday life}

The examination of the "four noble truths", as the basic concept of Buddhist philosophy, the universal truth, is useful to understand, how everyday life relates to the place and the sacred experience. The four truths are; pain, the origin of pain, stopping of pain and leads to its stopping. This could be understood by relating to the "ploughing ritual". Pain is the sensory feeling - sense and feeling of the mind-body experience by hard-working, by sensing the roughness of the earth, its impact and resistance of the body, body reactions to the heat of the sun and the climate, and the understanding of topography. Origin of the pain is the reason; which is earthly/physically bounded, by engaging in ploughing: interaction between ploughing and the topography. Pain and origin of the pain together lead to stopping, which creates the sanctity of no pain. An embodied landscape is a newly developing phenomenon in landscape research, describe this kind of experience of the body and the surrounding landscape. By the hard work of ploughing, sensing the pain and the origin of the pain bounded to the earth, the sense of place and the place attachment is experienced hence dwelling. These ploughing ceremonies indicate the boundary of ploughing/ cultivation/ agriculture as an essential process for the existence of the centre, the sanctity represented by monasteries in the centre of the place, physically in the city (Fig. 6). Therefore, ploughing and cultivation is a mechanism to engage the people, in the boundary of the place for the existence of the centre of the place and the city; as a performative process of dwelling to understand the existence on the earth, the essence of the nature of humans. Hard working in the field, increase the physical health, balancing metabolic conditions and maintaining a healthy body. After working in the fields, bathing in water tanks experience the refreshing/ sacred quality of water, in the vicinity of piers of stupas, across the paddy fields would refresh their bodies and minds uplifting the nature of humans and human well-being. As indicated elsewhere, from the seedling stage, up to the harvesting festivals, there are many rituals associated, as evidence of sacred experience in cultivation and ploughing. Therefore, it would have been so simple for the people, living during this period to understand the Buddhist philosophy and attained the higher levels of mind; most of them attained to the arhatship the highest level of the mind, or closer to that level by the guidance of Arhat Mahinda, and within the boundary level of the sacred city. 


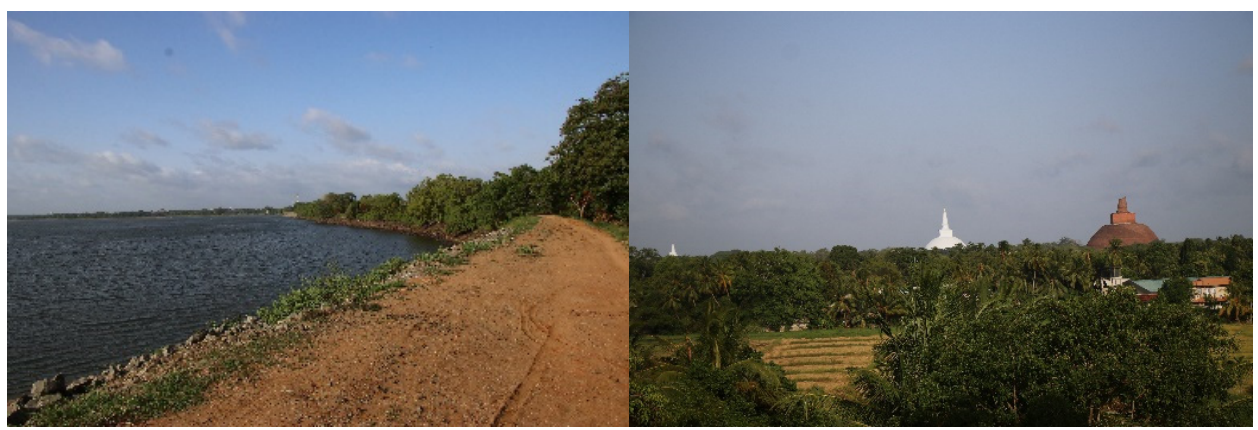

Figure 6: Centre - stupas and monasteries, and periphery - water and cultivation.

\subsection{Buddhist sacred city and urban sustainability}

During the time of arrival of Arhat Mahinda, the number of city dwellers may be more than 300,000 , according to the descriptions given in Mahavamsa. The new addition of water tanks around the city and its scale, is an evidence of the growth of urban population and the related developments for the creation of Buddhist sacred city, after the arrival of Arhat Mahinda. Devanampiyatissa has constructed two more water tanks; Thissa wewa and Nuwara wewa. The evidence of clay sediments, quarries as sources for building construction materials, at the tank bed of these tanks [17] for the vast construction of stupa and monasteries as interesting strategies highlight sustainable concepts. The Mahameghavana-garden was offered to the brotherhood after Arahat Mahinda has selected it as a fitting site for the purpose. This was the same area utilized as for a monastery during the Pandukabhaya period, later developed as Mahavihara, a Buddhist monastery, emphasise the parallels between the sacred orientation given by natural landscape and the religious understandings of sacred sites. It is further confirmed, by selecting all the appropriate points (site selection) by Arhat Mahinda, for the proposed developments; monasteries, warm baths, Uposatha-halls, refectory halls, point for the Bodhi tree, Tuparama, and Great Tupa. Relics of Gautama Buddha and a branch from the Bo tree Buddha seated for the attainment were brought to Sri Lanka during the reign of Devanampiyatissa. Tuparama was built in the marked spot, and Bodhi tree was planted at the same point selected before. Today, it is the oldest historical tree in the world. Great Tupa was built by a later king Duttugamunu (101-77 BCE) at the same marked spot. Several other monasteries and stupa were added in later periods, may have caused the gradually increasing the size of Thissa wewa and Nuwara wewa, due to the demand of building materials as well as to increase irrigation lands and the excess water supply for the city. The number of monks in three monasteries of Mahavihara, Abayagiriya and Jethawanaramaya during 5th century CE was roughly about 10,000 [18], and people gathering for worshiping would be more than 100,000 in certain festival seasons. The food donations for all of them was a popular meritorious act. Today, archaeological remains of monasteries and other buildings of ancient Anuradhapura city spread over 40 square kilometres of land area.

In the Buddhist sacred place of Anuradhapura centre is represented by the great stupas, resembling the mountains a vital element in the sacred landscape, while water tanks encircle the city attached with paddy fields and everyday life performance of people represent the periphery the boundary of the place (Fig. 7). Monasteries spread over large areas are prominent at the centre of the city. Therefore, a large number of monkhood who have attained 

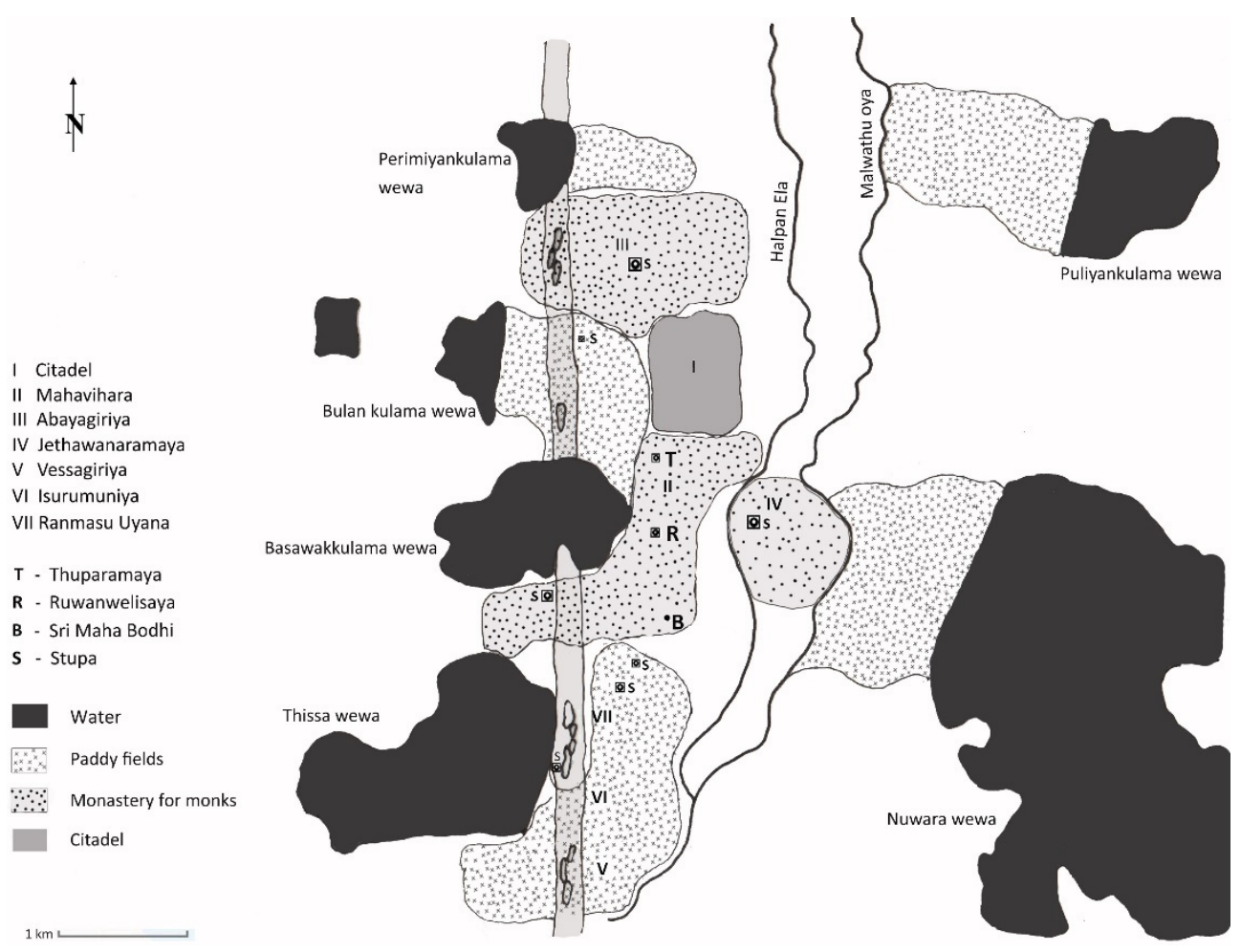

Figure 7: Buddhist sacred city, Anuradhapura.

to the higher ordination or near to the higher ordination depend on hard-working of the everyday life of the people, who are attached to the irrigation and cultivation lands at the periphery. Through hard working, well-being and serving to the centre, they also enter to the sanctity, higher levels of minds. All these create the Buddhist sacred city and atmosphere in Anuradhapura.

\section{CONCLUSION}

Anuradhapura sacred city has been examined to understand the urban agriculture apparent in city landscape to gain insight into current issues relating to feeding cities and the authenticity of food consumption. The paper discussed how the agriculture and urbanity co-exist by utilizing topography and geography, hence how a Buddhist sacred city has been shaped and evolved throughout history in Anuradhapura. The orientation of the city primarily guided by the natural landscape, guiding sacred dimensions, has been strengthened by an integrated system of irrigation and cultivation; experiencing peaceful balance in the city. The new demand due to the increasing number of population and related developments, due to the introduction of Buddhism, reshape the city to achieve a new balance integrating irrigation, cultivation and Buddhist concepts. The urban agriculture act as a mechanism of engaging the everyday life of the people with the landscape and uplift the nature of the humans and human well-being, hence establishes a healthy city, while enhancing the city form and the Buddhist sacred landscape. 


\section{ACKNOWLEDGEMENT}

Senate Research Council grants, University of Moratuwa, Sri Lanka.

\section{REFERENCES}

[1] Heidegger, M., Being and Time, Harper \& Row: New York, 1962.

[2] Norberg-Schulz, C., Genius Loci: Towards a Phenomenology of Architecture, Rizzoli: New York, 1980.

[3] De Silva, W., Performing place: Natural landscape, cultural place, performances of Sri Lankan traditional settlements, Kandy and Lankathilaka. $\mathrm{PhD}$ thesis, University of Nottingham UK, 2014 (published in e-prints, University of Nottingham); published in EThOS e-thesis, British Library, 2014.

[4] Herath, M.B., Archaeological remains of Thissa wewa Anuradhapura. Ancient Ceylon: Journal of the Department of Archaeology, 24, pp. 57-103, 2015.

[5] Eliade, M., Patterns in Comparative Religion, trans. R. Sheed, Cleveland: New York, 1965.

[6] Dereniyagala, S.U., The Prehistory of Sri Lanka: An Ecological Perspective, Archaeological Department: Sri Lanka, 1992.

[7] Wickramanayake, T.B., The beginnings of rice cultivation in Sri Lanka. Journal of the Royal Asiatic Society of Sri Lanka, 53, pp. 203-218, 2007.

[8] Chandraratne, R.M.M., Faunal remains from the gedige excavation in 1985. Ancient Ceylon: Journal of the Department of Archaeology, 24, pp. 1-13, 2015.

[9] Geiger, W., The Mahavamsa: The Great Chronicle of Ceylon, trans. Geiger in 1912, 3rd print, Buddhist cultural centre: Colombo, 2007.

[10] Rykwert, J., Idea of a Town: The Anthropology of Urban form in Rome, Italy and the Ancient World, Faber \& Faber: London, 1976.

[11] Sahasrabudhe, C. \& Kashyap, A., Festivals, rituals, and urban landscape in eighteenthcentury Maharashtra. South Asian Studies, 32(2), pp. 155-165, 2016. DOI: 10.1080/02666030.2016.1191810.

[12] Eliade, M., The Sacred and the Profane: The Nature of Religion, Harcourt: New York, 1968.

[13] Bollnow, O.F., Human Space, trans. C. Shuttleworth, ed. J. Kohlmaier, Hyphen: London, 2011.

[14] Norberg-Schulz, C., Existence, Space and Architecture, Praeger: London, 1971.

[15] Sinha, A., Landscapes in India: Forms and Meanings, University Press: Colorado, p. 36, 2006.

[16] Dharmasena, P.B., Evolution of hydraulic societies in the ancient Anuradhapura kingdom of Sri Lanka. Landscapes and Societies, eds. I. Martini \& W. Chesworth, Springer: Dordrecht, pp. 341-352, 2010.

[17] Wagalawatta, T., Bebermeier, W., Knitter, D., Kohlmeyer, K. \& Schutt, B., Ancient rock quarries in Anuradhapura Sri Lanka. eTopoi: Journal for Ancient Studies, 4, pp. 45-65, 2015.

[18] Seneviratna, A., Ancient Anuradhapura, Archaeological Survey Department: Colombo, 1994. 